\title{
Evaluating the Role of Information and Communication Technology (ICT) Support towards Processes of Management in Institutions of Higher Learning
}

\author{
Michael Okumu Ujunju \\ Dr. G. Wanyembi \\ Mr. Franklin Wabwoba \\ Department of Computer Science \\ Masinde Muliro University of Science and Technology
}

\begin{abstract}
The role of Information and Communication Technology in achieving organization's strategic development goals has been an area of constant debate, and as well perceived in different management dimensions. Most universities are therefore employing it (ICT) as a tool for competitive advantage to support the accomplishment of their objectives. Universities are also known to have branches or campuses that need strong and steady strategic plans to facilitate their steady expansion and growth. Besides, production of quality services from the various levels of management in these universities requires quality strategic plans and decisions. In addition, to realize the steady growth and competitive advantage, ICT not only has to be an additive but a critical component towards supporting management processes in the universities. This research sought to determine the role of ICT in supporting management processes in institutions of higher learning in Kenya. The research investigated how the different levels of management used ICT in their management processes and whether the use had any effect on management processes. The research further made recommendations to the universities on better use of ICTs in their management processes. A public university in Kenya was used as a case study in this research.
\end{abstract}

Keywords- ICT; Competitive advantage; Strategic management; Data.

\section{INTRODUCTION}

Information and communication technology (ICT) has become an important tool in modern management of universities. This is because information is a critical tool in facilitating management decisions and therefore, ICT is seen to be a crucial tool to help in facilitating acquisition of this information required in management decisions for universities. Manual and mechanical systems can no longer cope in the current demands of management processes in universities. This is due to the fact that accurate and timely data is a critical resource in planning and decision making (Acosta, 2004). To achieve this therefore, ICT must come in handy to facilitate the process of acquiring accurate and summarized data needed to facilitate management processes. It is in this context that there is dire need for a successful transition to the new technology in order for university managements to engage in quality management practices. Intranet and database systems are key components in the formation of ICT infrastructure, and hence their existence enhances greater management control by enabling departments in universities and their campuses to have greater access to information needed for management processes. This will enable them (managements) to function more effectively and efficiently, and since projections will be more accurate or now available, university managements can make long-term strategic plans during their management processes, (Nyandiere, 2007). Most of organizations endeavor to employ Information Communication Technology as a tool for competitive advantage for the accomplishment of the objective of organization as well as enhance the alignment between Information Communication Technology and management strategy, (Mohammed, 2010). To achieve the former, ICT has been leverage to improved service and lower the cost of conducting strategic management functions.

In the modern world of technology in which Universities exist, they (Universities) need ICT services since it plays a significant strategic role in the management of Universities. ICT makes it easy for a University's decision making because they have information at hand. With the aid of ICT, university managers have more information at their reach than ever before; modern ICT improves good organization and usefulness at each stage of the management decision making procedure. It is therefore imperative for Universities to take ICT seriously for the purpose of sustaining steady growth as a result of making quality and timely strategic plans. Without adequate level of ICT use, chances of making poor and untimely management decisions will prevail and this will constantly lead to the universities' stunted growth.

\section{THEORETICAL FRAMEWORK}

The research adopted the theory of organizational Information Processing developed by (Galbraith, 2005). The theory identifies three important concepts: information processing needs, information processing capability, and the fit between the two to obtain optimal performance in organizations. According to the theory, organizations need quality information to cope with environmental uncertainty 
and improve their decision making. Environmental uncertainty stems from the complexity of the environment and dynamism, or the frequency of changes to various environmental variables. The theory further postulates that, organizations have two strategies to cope with uncertainty and increased information needs for their management processes: (1) develop buffers to reduce the effect of uncertainty, and (2) implement structural mechanisms and information processing capability to enhance the information flow and thereby reduce uncertainty. The theory is presented as a model in Figure 1.

As it can be seen from the model, organization design strategy has sub units. These sub units require an integrated IT system that will improve information flow and reduce uncertainty within organizational sub units. Increasing the capacity to process information required in management processes will require (1) an investment in vertical information systems and (2) creation of lateral relations to portray an image of how the levels of management will interact in the management processes. Creation of slack resources and selfcontained tasks will reduce the need for information processing after a satisfactory confirmation that indeed output of a process doesn't require further intervention of an information processing system. Increasing the capacity to process information and reducing the need for information processing are products aimed at fulfilling management goals which are key entities of management.

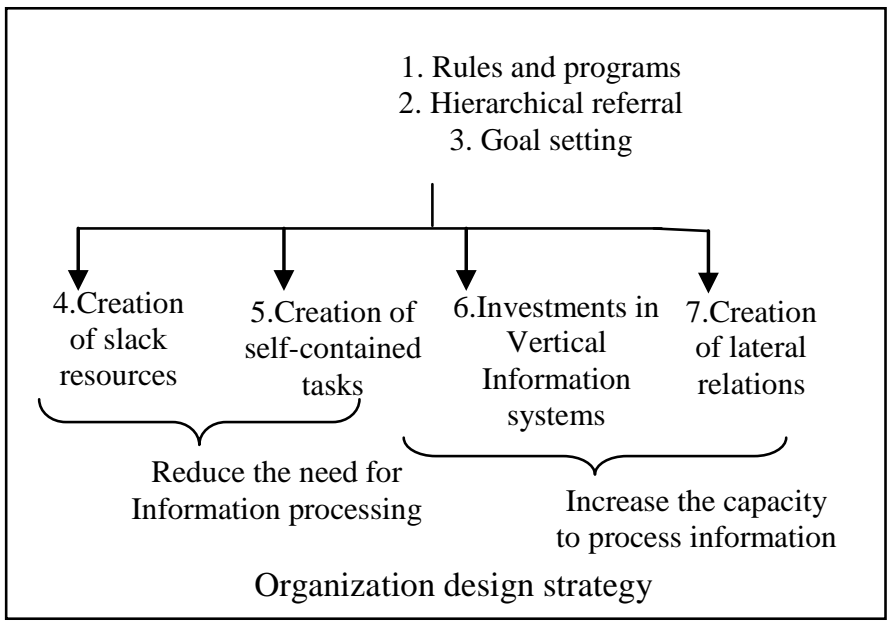

Fig I. Organizational Information processing model

Source: Galbraith (2005)

A lot was borrowed from this model for this research, especially when we talk of integrating ICT in management processes of universities in Kenya, and understanding that ICT can indeed play greater roles towards improving the processes of management in universities. The model was adopted because; accurate and timely information is a key element in management processes. Acquiring this information requires a processing model which cannot be complete without focusing on Information and Communications technology infrastructure.

\section{REVIEW OF RELATED LITERATURE}

\section{A. ICT in Management of Higher Learning Institutions}

Through the emergence of fast and powerful computers, networks and infrastructure, delivery of immediate and relevant information enables policymakers in an organization to make quick and accurate decisions,

(Newmann, 1994). (Laudon, 2003) while commenting on the role of information systems in organizations indicates that ICTs provide tools for data collection, analysis, storage and dissemination to support decision making in organization. University environments are equally changing in the technology front. Arising from his studies of Universities in Philippines (Asia), [1] notes that quick and accurate decisions of institutions of higher learning managers require readily available and relevant information thus making ICT a vital tool in today's business world providing tools for information collection, storage, and management to facilitate communication and decision making processes. He points out that institutions of higher learning too, must cope with the emerging trends of competing on the ICT platform, thus they need to continually assess their current status, and that of their competitors to formulate and manage their own strategies if only to stay abreast with the latest challenges of the information age. ICTs play and will continue playing an important role in higher education institutions (HEIs) management.

(Katz, 2001) quotes EDUCAUSE president, Brian Hawkins, who in 1999, in his paper Technology, Education, and the Very Foggy Crystal Ball asserted three propositions about the impact of ICT on higher education, that is;

a) That the new technology affords exciting opportunities for more effective teaching;

b) That the new technology offers scalability that is greatly needed;

c) That the new technology will transform higher education beyond what we know it to be today.

Technology has provided exciting opportunities for teaching and management including the recent e-learning initiatives in addition to transforming HEIs management operations. ICTs in higher educational institutions have come about from developments in corporate businesses where ICTs have been incorporated into organizational functions to improve their performance. As (Tusubira \& Mulira, 2005), having extensively studied operations of Makerere University (Uganda), argue that at the organizational level, the integration of ICT in organizational functions has been brought about by three main factors: increased efficiency, cost effectiveness, and competitiveness.

\section{RESEARCH METHOLOGY}

The research was conducted through case study. The study was concerned with determining the role played by information and communication technology in supporting management processes in institutions of higher learning. 
The sample size used was put into strata or groups, each stratum representing each of the three levels of management. Purposive sampling was then used where a group of people believed to be reliable enough for the study were targeted.

Questionnaires were used to collect data from staff in each of the three levels of management. They included both openend and closed-end questions. They were physically administered by the researcher to 107 respondents out of which 70 were responded to. Unstructured interviews were also conducted with the senior university management staff. All data collected were analyzed using qualitative and quantitative approaches which were facilitated using Statistical Program for Social Science (SPSS) version 17.0. Cross tabulations showing percentages and frequency distributions were used to analyze data collected.

\section{FINDINGS AND DISCUSSION}

The demographic information of respondents was presented and discussed based on gender and the possibility of having used ICT tools like a computer before for each respondent interviewed. This information is presented in tables and the figures.

Respondents were asked of their sex and close observation shows that there is a significant variation in the distribution by sex of staff as shown in Table 1. Findings in table 1 reveal that, male respondents were majority $(60 \%)$ compared to female respondents $(40 \%)$. These findings suggest that, there is a gender gap between women users of ICT and men, and that women are not well accessible to ICTs as compared to men. There is therefore need to mainstream gender concerns into the ICT arena by providing opportunities for ICT training and develop clear policies, guidelines and strategies to remove this gender gap that disadvantages women from accessing ICTs in institutions of higher learning.

In determining whether respondents had used ICT in their work procedures before, they were asked to state whether they had used ICT tools like a computer before. Results in Table II show that, many staffs $(98.6 \%)$ had used ICT tools. They were therefore not new to the technology. Knowledge of ICT is a factor that seemed to motivate employees to embrace and positively integrate ICT in management processes and work procedures.

Views on how ICT tools were used by staff in carrying out their duties is as shown in Table III. The various ways in which ICT is used in processes of management as established by the findings are supported by

(Ruiz-Mercader, 2006). In his statement he acknowledges that the best ways organizations use ICTs is to obtain, to report, to process, to accumulate and to exchange information. Furthermore in a knowledge management context, ICT can support transformation within and between tacit and explicit knowledge.

Views on how ICT tools had the impact on overall work performance of staff in different levels of management is as shown in Table IV.
TABLE I. RESPONDENTS' GENDER

\begin{tabular}{|rc|r|r|r|r|}
\hline & Frequency & Percent & \multicolumn{1}{c|}{$\begin{array}{c}\text { Valid } \\
\text { Percent }\end{array}$} & $\begin{array}{c}\text { Cumulative } \\
\text { Percent }\end{array}$ \\
\hline Valid & male & 42 & 60.0 & 60.0 & 60.0 \\
& female & 28 & 40.0 & 40.0 & 100.0 \\
& Total & 70 & 100.0 & 100.0 & \\
\hline
\end{tabular}

TABLE II. RESPONDENTS VIEW ON USE OF ICT TOOLS

\begin{tabular}{|c|c|c|c|c|}
\hline & Frequency & Percent & $\begin{array}{c}\text { Valid } \\
\text { Percent }\end{array}$ & $\begin{array}{c}\text { Cumulative } \\
\text { Percent }\end{array}$ \\
\hline Valid yes & 69 & 98.6 & 98.6 & 98.6 \\
\hline no & 1 & 1.4 & 1.4 & 100.0 \\
\hline Total & 70 & 100.0 & 100.0 & \\
\hline
\end{tabular}

TABLE III. ICT USE IN DUTIES OF MANAGEMENT

\begin{tabular}{|ll|r|r|r|r|}
\hline & & Frequency & Percent & $\begin{array}{c}\text { Valid } \\
\text { Percent }\end{array}$ & $\begin{array}{c}\text { Cumulative } \\
\text { Percent }\end{array}$ \\
\hline Valid & writing reports & 22 & 31.4 & 31.9 & 31.9 \\
& generating & 20 & 28.6 & 29.0 & 60.9 \\
& information & 4 & 5.7 & 5.8 & 66.7 \\
& leisure/games & 14 & 20.0 & 20.3 & 87.0 \\
& general typing & 9 & 12.9 & 13.0 & 100.0 \\
& E-mail and & & \\
& internet & 69 & 98.6 & 100.0 & \\
Total & 1 & 1.4 & & \\
Total & 99 & 70 & 100.0 & & \\
\hline
\end{tabular}

TABLE IV. IMPACT OF ICT TOOLS ON OVERALL WORK PERFORMANCE OF STAFF IN DIFFERENT LEVELS OF MANAGEMENT

\begin{tabular}{|l|r|r|r|r|}
\hline & Frequency & Percent & $\begin{array}{c}\text { Valid } \\
\text { Percent }\end{array}$ & $\begin{array}{c}\text { Cumulative } \\
\text { Percent }\end{array}$ \\
\hline Valid & $\begin{array}{l}\text { motivate to } \\
\text { maximize } \\
\text { potential } \\
\text { de- } \\
\text { motivates } \\
\text { and reduce } \\
\text { performance }\end{array}$ & 44.3 & 34.3 & 34.3 \\
$\begin{array}{l}\text { simplify } \\
\text { work and } \\
\text { makes it } \\
\text { easier } \\
\text { facilitate } \\
\text { acquisition } \\
\text { of realistic } \\
\text { plans }\end{array}$ & 28 & 40.0 & 5.7 & 40.0 \\
$\begin{array}{l}\text { quality } \\
\text { results from } \\
\text { staff } \\
\text { Total }\end{array}$ & 5 & 7.1 & 7.1 & 80.0 \\
\hline
\end{tabular}




\section{SUGGESTION For FUtURE RESEARCH}

This research was conducted in a public university and the results may not be generalized to private universities due to different operational dynamics. It would be worthwhile if further research was conducted to establish if the same results would work for private universities in Kenya.

\section{CONCLUSION}

The research determined and evaluated the role of ICTs in supporting processes of management in institutions of higher learning in Kenya. There was a gender gap between women users of ICTs and men in their work of management as per the results in Table 1, which showed $40 \%$ for women users and $60 \%$ for men. There is total need for this gap to be removed. Views of respondents on the use of ICT tools were very positive $(98.6 \%)$. This shows that ICT use in management is highly embraced and this improves management practices. From Table 3, it could be seen that ICT tools are used in a number of ways in supporting duties of management. This is an indicator of positive acceptance by staff on embracing ICTs in their duties of management. The use of ICT in works of universities management is observed that indeed, it simplifies work and makes it easier for universities' staff to enjoy their work and hence generate quality decisions for the running of their universities.

\section{RECOMMENDATIONS}

This research gives the following suggestions as recommendations for better use of ICTs in processes of management in institutions of higher learning;

1) Provide opportunities for ICT training and develop clear policies, guidelines and strategies for better use of ICT equipment by all, regardless of sex.

2) All affected users should be trained properly on any new upcoming software or computer hardware constituting ICT infrastructure.

Universities should use current ICTs technologies as possible in all areas of operations so that to maintain consistency in their modern management practices if quality management has to be maintained.

3) Use ICT resources only for authorized purposes to avoid abusing the resources in process of executing duties.

4) ICT resources can be shared. There is needed to be considerate in the use of shared resources. Refrain from monopolizing systems, overloading networks with excessive data, degrading services, wasting ICT resource time, disk space, manuals or other resources.

\section{REFERENCES}

[1] Acosta F.R. (2004), Information Technology Strategic Plan of Olivarez College unpublished doctoral dissertation, University of Baguio, Philippines.

[2] Nyandiere, C. (2007). Increasing role of computer-based information systems in the management of higher education institutions. In M. Kashorda, F. Acosta and C. Nyandiere (eds). ICT Infrastructure, Applications, Society and Education: Proceedings of the Seventh Annual Strathmore University ICT Conference. Strathmore University Press: Nairobi

[3] Mohammed, A. H., Altemini, M.S, \& Yahya Y. (2010). Evaluating the performance of Information Technology on Strategic Planning, International Journal of Education and Development using ICT (IJEDICT).

[4] Galbraith, J.R. (2005) Designing Complex Organizations. Reading. MA: Addison-Wesley

[5] Newmann, S. (1994). Strategic information systems - Competition through information technologies. New York:Macmillan.

[6] Laudon, K.C. and Laudon J.P.(2003): Management Information Systems: Managing the Digital Firm, 7th ed., New Jersey: Prentice-Hall.

[7] Katz, R. N. (2001) "The ICT Infrastructure: A Drive for Change" EDUCAUSE Review.

[8] Tusubira,F F \& Mulira, N. (2005). Integration of ICT in Higher Education Institutions: Challenges and best practice recommendations based on experience of Makerere University \& Other organisations. Makerere University.

[9] Ruiz-Mercader J., Merono-Cerdan A. L., Sabater-Sanchez R. (2006), "Information technology and learning: Their relationship and impact on organisational performance in small businesses", International Journal of Information Management, Volume 26, Issue 1, February 2006, pp. 1629. 